\title{
Biological pretreatment of wheat straw: Effect of fungal culturing on enzymatic hydrolysis of carbohydrate polymers
}



\section{Research Article}

Keywords: Lignin degradation, Wheat straw, White-rot fungi, Biological pretreatment, Enzymatic hydrolysis

Posted Date: February 18th, 2021

DOI: https://doi.org/10.21203/rs.3.rs-227697/v1

License: (c) (i) This work is licensed under a Creative Commons Attribution 4.0 International License. Read Full License 


\section{Abstract}

The aim of the study was comparative analysis of degradation of wheat straw lignin by white-rot fungi and its implications on the efficiency of enzymatic hydrolysis of holocellulose. Cyclocybe cylindracea, Ganoderma resinaceum, Irpex lacteus, Pleurotus ostreatus and Trametes versicolor were the species studied. Peroxidases were predominantly responsible for lignin degradation even though high laccase activities were detected, except in the case of Irpex lacteus where laccase activity was not detected. Studied fungal species showed various ability to degrade lignin in wheat straw which further affected release of reducing sugars during enzymatic saccharification. The highest rate of lignin degradation was noticed in sample pretreated with Irpex lacteus $(50.9 \pm 4.1 \%)$. Among all tested species only Ganoderma resinaceum was suitable lignin degrader with the 2 -fold higher hydrolysis yield $(51.1 \pm 4.7 \%)$ than in the control, and could have significant biotechnological application due to lower cellulose loss. A key mechanism of carbohydrate component convertibility enhancement was lignin removal in the biomass. Long time consumption, the low sugar yields and unpredictable fungal response still remain the challenge of the fungal pretreatment process.

\section{Introduction}

The global demands for energy today are considerably dependent on fossil fuels but the opportunities for exploitation of renewable energy sources are increasingly growing. In this perspective, conversion of biomass, as renewable energy source, into second generation biofuels is a promising approach in green energy technologies, bio-based economy and society devoted to sustainable development ${ }^{1}$.

Lignocellulose is a major component of plant biomass and is primarily composed of cellulose, hemicellulose and lignin that form a complex composite structure ${ }^{2}$. Chemical composition recommends this feedstock for utilization in technological processes based on a sugar platform, where cellulose or holocellulose are hydrolyzed to monosaccharides which are further converted into bioethanol or other chemicals ${ }^{3}$. However, lignin as a high complex aromatic polymer with a three-dimensional structure is mostly responsible for the recalcitrance of this potentially valuable raw material, which is an obstacle that hinders economically feasible conversion of holocellulose to fermentable sugars ${ }^{4,5}$. Thus, delignification is an inevitable step in lignocellulose processing rendering the cellulose and hemicellulose more exposed to enzymatic saccharification ${ }^{6}$. Recently, several bio-refinery concepts have been established for converting renewable biomass to fuels but pretreatment of plant residues still remains mostly physical, physico-chemical and chemical. Contrary, biological pretreatment deserves much more attention as it is safe, environmentally friendly and less energy intensive compared to other pretreatment methods. This approach comprises of using different microorganisms to remove lignin with a minimal loss of carbohydrate polymers ${ }^{7}$. However, the rate of hydrolysis reaction is very low and requires a great improvement to be commercially applicable ${ }^{8}$.

Although some groups of bacteria are capable to degrade lignin, white-rot fungi are considered as the most effective lignin degrading organisms ${ }^{9}$. Fungal degradation of lignin is extracellular oxidative process catalyzed by ligninolytic enzymes, mostly laccase, lignin peroxidases and $\mathrm{Mn}$-oxidizing peroxidase ${ }^{10}$. Some white rot fungi degrade lignin non-selectively depolymerising both cellulose and hemicelluloses, so holocellulose loss could range between 17 an $50 \%$, resulting in decreased yield of saccharification products ${ }^{11}$. On the other hand, fungal species that exhibit selective lignin degradation have higher affinity for lignin and degrade it faster than holocellulose, though the loss of carbohydrates decreases. Relation between those two polymers losses is a crucial parameter characterizing efficiency of biological pretreatment of lignocellulose and varies among species and even among strains of the same species ${ }^{11,12}$.

Previously has been shown that wheat straw can be considered as a promising substrate for ligninolytic enzymes production by cultivating various white-rot fungal species ${ }^{12,13,14,15}$. However, the effects of fungal culturing as a pretreatment method in lignocelluloses processing are not yet well understood. The aim of this study was to assess the white-rot fungal delignification mechanisms crucial to enhance efficiency of enzymatic saccharification of wheat straw after solid-state culturing.

\section{Results}

Activity of ligninolytic enzymes

Studied five species of macromycetes have shown different levels of MnP, MnIP and laccase activities after 5, 10, 15 and 19 days of solid-state cultivation on wheat straw as a substrate (Fig. 1). Based on the results of ligninolytic enzyme activities it can be noticed that activities levels varied during the fungal cultivation.

The highest level of $\mathrm{MnP}$ activity was detected in Pleurotus ostreatus with the maximum activity recorded after 10 days of cultivation ( $996.2 \pm$ $\left.69.1 \mathrm{U} \mathrm{L}^{-1}\right)$, while the lowest activity was noticed in Cyclocybe cylindracea after 15 days of cultivation $\left(8.5 \pm 2.3 \mathrm{U} \mathrm{L}^{-1}\right)$.

The maximum value of MnIP activities was also noted in $P$. ostreatus $\left(984.2 \pm 84.7 \mathrm{U} \mathrm{L}^{-1}\right)$ after 10 days of cultivation, and the minimum activity was measured in C. cylindracea after 10 days of cultivation $\left(9.5 \pm 3.8 \mathrm{UL}^{-1}\right)$. 
All studied species, except Irpex lacteus, were good producers of laccase with activities much higher in comparison with Mn-oxidizing peroxidases. High laccase activities characterized initial stages of fungal cultivation, between day 5 and day 10 , while activities of this enzyme were considerably lower at day 19 . Even though the highest level of laccase activity was detected in $P$. ostreatus $\left(15051.3 \pm 1186.9 \mathrm{U} \mathrm{L}^{-1}\right)$, Ganoderma resinaceum and $C$. cylindracea were better producers of this enzyme keeping the high laccase production till day 15 of fungal cultivation. The lowest laccase activity was detected in P. ostreatus $\left(3003.4 \pm 839.0 \mathrm{UL}^{-1}\right)$ after 19 days of cultivation. I. lacteus was the only studied species which did not synthesize laccase under experimental conditions. Trametes versicolor showed persistent activity of both MnP and MnIP during whole period of cultivation except at the beginning.

By comparing four groups that refer to data (all species included) obtained after 5, 10, 15 and 19 days, for each enzyme separately, the most significant difference was observed for laccase $(P<0.01)$ according to one-way ANOVA.

Wheat straw polymers degradation during biological pretreatment

To evaluate the effect of fungal culturing on degradation of wheat straw the change in content of three main polymers was determined.

Content of lignin, hemicellulose and cellulose in the wheat straw were $9.0 \pm 0.4 \%, 32.8 \pm 0.6 \%$ and $47.6 \pm 1.1 \%$, respectively. Pretreatment with studied fungal species caused significant variations in the total dry matter weight loss, bringing to the change of content of main polymers $(P<$ 0.01) (Table 1). Polymer degradation occurred continually during the cultivation period, so the maximum degradation rates were noted after 19 days. The maximum dry matter weight loss was noted after pretreatment with $I$. lacteus $(40.1 \pm 2.0 \%)$, and the minimum was detected after cultivation of $C$. cylindracea $(16.1 \pm 0.6 \%)$. Statistically significant difference between studied fungal taxa when dry matter weight loss is considered as a quantitative variable (taking into account all data from the beginning to the end of the experiment) is confirmed by one-way ANOVA $(P<0.01)$. According to performed Tukey post-hoc test, significant differences $(\mathrm{P}<0.01)$ are observed between $I$. lacteus and all other studied species except T. versicolor, meaning that in term of dry matter weight loss I. lacteus can be distinguished from other species. 
Table 1

Effect of biological pretreatment with selected white rot fungi on degradation of wheat straw polymers

\begin{tabular}{|c|c|c|c|c|c|c|c|c|c|}
\hline \multirow[t]{2}{*}{ Species/Sample } & \multirow{2}{*}{$\begin{array}{l}\text { Code of } \\
\text { strain }\end{array}$} & \multirow{2}{*}{$\begin{array}{l}\text { Period of } \\
\text { cultivation } \\
\text { (day) }\end{array}$} & \multirow{2}{*}{$\begin{array}{l}\text { Total dry } \\
\text { matter } \\
\text { weight loss } \\
\text { after } \\
\text { pretreatment } \\
\text { (\%) }\end{array}$} & \multicolumn{3}{|c|}{ Polymer content in sample ( $\mathrm{mg} \mathrm{g}^{-1}$ ) } & \multicolumn{3}{|c|}{ Degraded fibres (\%) } \\
\hline & & & & Lignin & Hemicellulose & Cellulose & Lignin & Hemicellulose & Cellulose \\
\hline \multirow[t]{4}{*}{$\begin{array}{l}\text { Cyclocybe } \\
\text { cylindracea }\end{array}$} & \multirow[t]{4}{*}{ BEOFB1210 } & 5 & $10.0 \pm 0.1$ & $\begin{array}{l}80.0 \\
\pm 2.6\end{array}$ & $293.0 \pm 2.9$ & $\begin{array}{l}443.0 \pm \\
5.8\end{array}$ & $\begin{array}{l}20.5 \\
\pm 2.6\end{array}$ & $19.6 \pm 0.8$ & $\begin{array}{l}16.2 \pm \\
0.1\end{array}$ \\
\hline & & 10 & $10.9 \pm 0.2$ & $\begin{array}{l}79.7 \\
\pm 2.4\end{array}$ & $285.7 \pm 1.8$ & $\begin{array}{l}403.0 \pm \\
3.5\end{array}$ & $\begin{array}{l}21.6 \\
\pm 2.4\end{array}$ & $22.5 \pm 0.4$ & $\begin{array}{l}24.6 \pm \\
0.7\end{array}$ \\
\hline & & 15 & $13.9 \pm 0.7$ & $\begin{array}{l}76.7 \\
\pm 1.9\end{array}$ & $288.0 \pm 4.0$ & $\begin{array}{l}409.3 \pm \\
3.4\end{array}$ & $\begin{array}{l}27.1 \\
\pm 2.3\end{array}$ & $24.4 \pm 1.6$ & $\begin{array}{l}26.0 \pm \\
0.0\end{array}$ \\
\hline & & 19 & $16.1 \pm 0.6$ & $\begin{array}{l}71.0 \\
\pm 2.1\end{array}$ & $286.3 \pm 8.2$ & $\begin{array}{l}384.7 \pm \\
10.9\end{array}$ & $\begin{array}{l}34.3 \\
\pm 2.1\end{array}$ & $26.8 \pm 2.6$ & $\begin{array}{l}32.3 \pm \\
1.7\end{array}$ \\
\hline \multirow[t]{4}{*}{$\begin{array}{l}\text { Ganoderma } \\
\text { resinaceum }\end{array}$} & \multirow[t]{4}{*}{ BEOFB440 } & 5 & $9.8 \pm 0.6$ & $\begin{array}{l}77.3 \\
\pm 0.3\end{array}$ & $321.0 \pm 5.0$ & $\begin{array}{l}426.0 \pm \\
8.4\end{array}$ & $\begin{array}{l}23.0 \\
\pm 0.8\end{array}$ & $11.8 \pm 1.6$ & $\begin{array}{l}19.3 \pm \\
1.2\end{array}$ \\
\hline & & 10 & $13.4 \pm 0.4$ & $\begin{array}{l}79.0 \\
\pm 1.5\end{array}$ & $268.0 \pm 3.6$ & $\begin{array}{l}382.3 \pm \\
9.2\end{array}$ & $\begin{array}{l}24.5 \\
\pm 1.6\end{array}$ & $29.3 \pm 0.7$ & $\begin{array}{l}30.4 \pm \\
1.9\end{array}$ \\
\hline & & 15 & $17.3 \pm 0.4$ & $\begin{array}{l}68.0 \\
\pm 0.6\end{array}$ & $243.0 \pm 8.3$ & $\begin{array}{l}381.0 \pm \\
4.5\end{array}$ & $\begin{array}{l}37.9 \\
\pm 0.7\end{array}$ & $38.8 \pm 2.0$ & $\begin{array}{l}33.8 \pm \\
0.9\end{array}$ \\
\hline & & 19 & $19.6 \pm 0.9$ & $\begin{array}{l}62.7 \\
\pm 6.4\end{array}$ & $228.7 \pm 1.2$ & $\begin{array}{l}390.0 \pm \\
11.1\end{array}$ & $\begin{array}{l}44.5 \\
\pm 5.4\end{array}$ & $44.0 \pm 0.3$ & $\begin{array}{l}34.1 \pm \\
2.5\end{array}$ \\
\hline \multirow[t]{4}{*}{ Irpex lacteus } & \multirow[t]{4}{*}{ BEOFB1910 } & 5 & $14.9 \pm 0.7$ & $\begin{array}{l}82.3 \\
\pm 1.7\end{array}$ & $302.3 \pm 6.0$ & $\begin{array}{l}377.7 \pm \\
4.2\end{array}$ & $\begin{array}{l}22.6 \\
\pm 1.6\end{array}$ & $21.6 \pm 2.0$ & $\begin{array}{l}32.5 \pm \\
0.3\end{array}$ \\
\hline & & 10 & $23.4 \pm 0.9$ & $\begin{array}{l}71.3 \\
\pm 3.0\end{array}$ & $276.0 \pm 7.6$ & $\begin{array}{l}362.0 \pm \\
10.1\end{array}$ & $\begin{array}{l}39.8 \\
\pm 1.8\end{array}$ & $35.6 \pm 2.4$ & $\begin{array}{l}41.7 \pm \\
2.3\end{array}$ \\
\hline & & 15 & $32.2 \pm 0.4$ & $\begin{array}{l}68.7 \\
\pm 0.3\end{array}$ & $266.3 \pm 7.5$ & $\begin{array}{l}349.7 \pm \\
3.5\end{array}$ & $\begin{array}{l}48.6 \\
\pm 0.5\end{array}$ & $45.0 \pm 1.3$ & $\begin{array}{l}50.2 \pm \\
0.3\end{array}$ \\
\hline & & 19 & $40.1 \pm 2.0$ & $\begin{array}{l}74.3 \\
\pm 5.8\end{array}$ & $253.0 \pm 4.5$ & $\begin{array}{l}300.7 \pm \\
16.8\end{array}$ & $\begin{array}{l}50.9 \\
\pm 4.1\end{array}$ & $53.9 \pm 1.1$ & $\begin{array}{l}62.0 \pm \\
3.3\end{array}$ \\
\hline \multirow[t]{4}{*}{$\begin{array}{l}\text { Pleurotus } \\
\text { ostreatus }\end{array}$} & \multirow[t]{4}{*}{ HAI592 } & 5 & $7.4 \pm 0.3$ & $\begin{array}{l}83.0 \pm \\
3.1\end{array}$ & $299.7 \pm 3.4$ & $\begin{array}{l}446.3 \pm \\
2.7\end{array}$ & $\begin{array}{l}15.2 \\
\pm 2.9\end{array}$ & $15.5 \pm 0.7$ & $\begin{array}{l}13.2 \pm \\
1.7\end{array}$ \\
\hline & & 10 & $14.5 \pm 0.9$ & $\begin{array}{l}90.0 \\
\pm 1.0\end{array}$ & $299.7 \pm 5.4$ & $\begin{array}{l}409.0 \pm \\
10.3\end{array}$ & $\begin{array}{l}15.1 \\
\pm 0.5\end{array}$ & $22.0 \pm 0.6$ & $\begin{array}{l}26.5 \pm \\
2.4\end{array}$ \\
\hline & & 15 & $15.7 \pm 0.9$ & $\begin{array}{l}83.0 \\
\pm 4.2\end{array}$ & $277.7 \pm 5.0$ & $\begin{array}{l}415.7 \pm \\
6.6\end{array}$ & $\begin{array}{l}22.8 \\
\pm 3.6\end{array}$ & $28.7 \pm 2.0$ & $\begin{array}{l}26.4 \pm \\
1.8\end{array}$ \\
\hline & & 19 & $17.5 \pm 1.0$ & $\begin{array}{l}80.3 \\
\pm 0.9\end{array}$ & $263.7 \pm 2.0$ & $\begin{array}{l}406.0 \pm \\
6.2\end{array}$ & $\begin{array}{l}26.8 \\
\pm 1.7\end{array}$ & $33.7 \pm 0.3$ & $\begin{array}{l}29.6 \pm \\
1.6\end{array}$ \\
\hline \multirow[t]{4}{*}{$\begin{array}{l}\text { Trametes } \\
\text { versicolor }\end{array}$} & \multirow[t]{4}{*}{ BEOFB321 } & 5 & $6.2 \pm 1.2$ & $\begin{array}{l}75.0 \\
\pm 1.2\end{array}$ & $266.7 \pm 7.2$ & $\begin{array}{l}466.0 \pm \\
2.5\end{array}$ & $\begin{array}{l}22.3 \\
\pm 1.1\end{array}$ & $23.7 \pm 1.9$ & $8.2 \pm 1.2$ \\
\hline & & 10 & $15.9 \pm 1.7$ & $\begin{array}{l}69.7 \\
\pm 2.2\end{array}$ & $270.3 \pm 5.0$ & $\begin{array}{l}400.7 \pm \\
13.2\end{array}$ & $\begin{array}{l}35.3 \\
\pm 2.6\end{array}$ & $30.7 \pm 2.2$ & $\begin{array}{l}29.1 \pm \\
3.7\end{array}$ \\
\hline & & 15 & $26.2 \pm 2.1$ & $\begin{array}{l}71.0 \\
\pm 1.2\end{array}$ & $251.0 \pm 7.0$ & $\begin{array}{l}375.0 \pm \\
7.2\end{array}$ & $\begin{array}{l}42.2 \\
\pm 2.0\end{array}$ & $43.5 \pm 3.1$ & $\begin{array}{l}42.0 \pm \\
0.7\end{array}$ \\
\hline & & 19 & $32.7 \pm 1.1$ & $\begin{array}{l}73.0 \\
\pm 4.0\end{array}$ & $225.7 \pm 4.9$ & $\begin{array}{l}368.7 \pm \\
5.2\end{array}$ & $\begin{array}{l}45.8 \\
\pm 3.1\end{array}$ & $53.7 \pm 3.1$ & $\begin{array}{l}47.9 \pm \\
1.4\end{array}$ \\
\hline \multicolumn{2}{|c|}{ Untreated wheat straw } & - & - & $\begin{array}{l}90.6 \\
\pm 4,3\end{array}$ & $328.2 \pm 5,5$ & $\begin{array}{l}476.0 \pm \\
11.4\end{array}$ & - & - & - \\
\hline \multicolumn{2}{|c|}{$\begin{array}{l}\text { Chemically pretreated wheat } \\
\text { straw }\end{array}$} & - & $36.0 \pm 0.0$ & $\begin{array}{l}60.7 \\
\pm 1.3\end{array}$ & $160.0 \pm 2.5$ & $\begin{array}{l}699.3 \pm \\
4.9\end{array}$ & $\begin{array}{l}57.1 \\
\pm 0.9\end{array}$ & $68.8 \pm 0.5$ & $6.0 \pm 0.7$ \\
\hline
\end{tabular}

The rates of polymers degradation in wheat straw differed among studied species (Table 1). In some occasions ( $T$. versicolor, $P$. ostreatus and G. resinaceum) capacities of studied species to degrade hemicelluloses were significantly higher in comparison with their abilities to degrade cellulose. The highest rate of lignin, hemicelluloses and cellulose degradation was noted after pretreatment with 1 . lacteus ( $50.9 \pm 4.1 \%, 53.9 \pm$ 
$1.1 \%$ and $62.0 \pm 3.3 \%$, respectively). The lowest rate of lignin and cellulose degradation was noted after pretreatment with $P$. ostreatus ( $26.8 \pm$ $1.7 \%$ and $29.6 \pm 1.6 \%$, while the minimum hemicelluloses degradation was achieved after pretreatment with $C$. cylindracea (26.8 $\pm 2.6 \%$ ).

Compared with other species, G. resinaceum achieved the maximum difference between the level of lignin and cellulose degradation rates (44.5 $\pm 5.4 \%$ vs. $34.1 \pm 2.5 \%$ ) which characterized this species as the most selective in delignification among all studied fungal species. One-way ANOVA was used to assess the difference between all fungal species considering rates of degradation, separately for lignin, hemicellulose and cellulose. Significant difference was confirmed between fungal species toward all three polymers $(P<0.01)$. Tukey post-hoc test was also performed and for lignin, significant differences $(\mathrm{P}<0.01)$ were observed between $P$. ostreatus and all studied fungal species, except $C$. cylindracea, as well as between $C$. cylindracea and $I$. lacteus. Considering hemicelluloses, significant differences are observed between $C$. cylindracea and I. lacteus, C. cylindracea and T. versicolor, I. lacteus and P. ostreatus, P. ostreatus and T. versicolor. For cellulose, I. Iacteus stands out considering the degradation of this polymer, because significant difference is observed between this and all other tested species.

The PCA showing relationship between degradation of lignin and enzyme activity of each species (separately for MnP, MnIP and laccase), was shown on Fig. 2. Vectors referring to the degradation of lignin by fungal species are oriented toward the left side of the ordination diagrams and correlate to supplementary variables referring to the final stage of the experiment (D19 and D15). However, enzyme activities of studied species varied and showed different correlations with lignin degradation depending on the enzyme.

In Fig. 2a that refers to MnP, the positive correlation between lignin degradation by I. lacteus, T. versicolor and G. resinaceum and their enzyme activities was observed. This Figure also illustrates the positive correlation between supplementary variables MnP activity of $P$. ostreatus and D10, while negative one is seen between MnP activity of C. cylindracea and D15, as presented in Sect. 3.1.

As seen from Fig. 2b, MnIP activity of $P$. ostreatus was positively correlated with supplementary variable D10, but the correlation with lignin degradation by this species was almost non-existent. On the other hand, enzyme activities of other species were highest after D19 and D15 and were positively correlated with the degree of lignin degradation.

Vectors referring to laccase activities of fungal species are oriented toward the right side of the ordination diagram confirming high laccase activities in the initial stages of fungal cultivation (Fig. 2c). Contrary to the MnP and MnIP, laccase activity of all taxa was negatively correlated with the degradation of lignin.

Enzymatic hydrolysis of wheat straw

Two crucial factors affecting the hydrolysis process with predefined conditions, enzyme loading and particle size were investigated to determine the optimal parameters for further enzymatic hydrolysis of pretreated wheat straw.

As shown in Fig. 3, the reducing sugars production profiles in all investigated samples were similar i.e. continual increase occurred during the hydrolysis. Using the different concentrations of cellulase $(0.5 ; 1.0$ and $2.0 \mu \mathrm{L} / \mathrm{mL})$ to determine the optimal concentration of enzyme required for wheat straw saccharification, continual increase of reducing sugars concentration in hydrolysate was noticed in the period of $72 \mathrm{~h}$ (Fig. $3 \mathrm{a}$ ). Hydrolysis rate of untreated wheat straw depended on the cellulase concentration to the certain level, so the lowest value of released sugars was detected at enzyme loading of $0.5 \mu \mathrm{L} / \mathrm{mL}\left(5.3 \pm 0.2 \mathrm{gGE} \mathrm{L}^{-1}\right)$. The highest content of reducing sugars was achieved at enzyme loading of 1.0 $\mu \mathrm{L} / \mathrm{mL}\left(6.0 \pm 0.1 \mathrm{gGE} \mathrm{L}^{-1}\right)$ after $72 \mathrm{~h}$, and was not further increased with the enzyme loading of $2.0 \mu \mathrm{L} / \mathrm{mL}$ (Fig. 3a).

Obtained results showed that the particle size of wheat straw used for enzymatic hydrolysis significantly affect the rate of reducing sugars release $(P<0.01)$. Correspondingly, the highest content of reducing sugars in hydrolysate was detected after $72 \mathrm{~h}$ in samples containing $S$ fraction $\left(6.0 \pm 0.1 \mathrm{gGE} \mathrm{L}^{-1}\right)$, while the minimum was noticed in samples with $L$ fraction $\left(2.5 \pm 0.0 \mathrm{gGE} \mathrm{L}^{-1}\right)$ (Fig. $\left.3 \mathrm{~b}\right)$.

Fungal culturing was further conducted with $S$ fraction to investigate the effect of ligninolytic enzymes secretion by selected white-rot fungi on the release of reducing sugars during enzymatic hydrolysis of pretreated wheat straw. Pretreatment of wheat straw with selected white rot fungi differently affected the rate of reducing sugars release during the enzymatic hydrolysis (Fig. 4). Maximum amount of reducing sugars was released from wheat straw pretreated with $G$. resinaceum $\left(7.3 \pm 0.5 \mathrm{gGE} \mathrm{L}^{-1}\right)$, while the minimum was detected after pretreatment with $C$. cylindracea $\left(1.3 \pm 0.1 \mathrm{gGE} \mathrm{L}^{-1}\right.$ ) (Fig. 4). Results indicates that among all tested fungal species only pretreatment with $G$. resinaceum increased total sugar yield for $21.7 \%$ compared with the control, while wheat straw processing with other tested species brought to lower sugar yields during saccharification.

Enzymatic hydrolysis of chemically pretreated wheat straw obtained significantly higher amount of reducing sugars compared to biologically pretreated straw, and the maximum amount was achieved after $72 \mathrm{~h}\left(18.2 \pm 0.2 \mathrm{gGE} \mathrm{L}^{-1}\right.$ ) (Fig. 5). Significant differences considering time, as well as fungal species, were confirmed by one-way ANOVA $(P<0.01)$ when reducing sugars are used as a quantitative variable. Significant differences between all species pairs were assessed using Tukey post-hoc test, according to which $C$. cylindracea and $G$. resinaceum were separated, confirming that they have the most different effect on concentration of reducing sugars. 
The efficiency of the pretreatment was evaluated by enzymatic convertibility of substrate expressed through hydrolysis yield and coefficient of conversion. The highest hydrolysis yield characterized chemically pretreated samples $(70.2 \pm 0.8 \%)$ (Table 2$)$. Obtained results also showed that differences in hydrolysis yields occurred depending on fungal species used for the pretreatment. Among pretreated samples a maximum convertibility was determined for samples pretreated with $G$. resinaceum with the highest hydrolysis yield $(51.1 \pm 4.7 \%)$, which was considerably higher than in untreated wheat straw $(34.2 \pm 0.3 \%)$. In all other samples lower values of hydrolysis yields were achieved. The minimum was noticed after saccharification of samples pretreated with $C$. cylindracea ( $9.4 \pm 0.5 \%)$. Even thought high hydrolysis yield was achieved after pretreatment with $G$. resinaceum, coefficient of conversion that refers to a starting sample indicates that difference in enzymatic convertibility among this sample and the control is found negligible ( 0.335 and 0.341 , respectively). The highest $K_{c}$ of chemically pretreated wheat straw ( 0.660 from theoretical maximum value) distinguishes this method as the most effective in comparison with pretreated samples (Table 2 ).

Table 2

Sugar composition of the enzymatic hydrolysates from pretreated wheat straw

\begin{tabular}{|lllll|}
\hline Pretreatment & \multicolumn{3}{c|}{ Sugar concentration g L-1 } \\
\cline { 2 - 5 } & Glucose & Cellobiose & Arabinose & Xylose \\
\hline Cyclocybe cylindracea & $1.5 \pm 0.0$ & $4.1 \pm 0.1$ & $1.2 \pm 0.0$ & $3.7 \pm 0.0$ \\
\hline Ganoderma resinaceum & $5.5 \pm 0.0$ & $13.9 \pm 0.2$ & $7.2 \pm 0.1$ & $12.8 \pm 0.3$ \\
\hline Irpex lacteus & $3.6 \pm 0.2$ & $14.8 \pm 0.2$ & $6.3 \pm 0.0$ & $12.4 \pm 0.2$ \\
\hline Pleurotus ostreatus & $4.7 \pm 0.1$ & $13.3 \pm 0.1$ & $8.7 \pm 0.0$ & $10.3 \pm 0.1$ \\
\hline Trametes versicolor & $3.1 \pm 0.1$ & $19.2 \pm 0.5$ & $18.0 \pm 0.3$ & $17.9 \pm 0.2$ \\
\hline NaOH & $18.4 \pm 0.2$ & $4.0 \pm 0.1$ & $0.6 \pm 0.0$ & $0.6 \pm 0.0$ \\
\hline Control & $7.2 \pm 0.0$ & $14.4 \pm 0.1$ & $4.6 \pm 0.0$ & $42.7 \pm 1.2$ \\
\hline
\end{tabular}

Samples of the enzymatic hydrolysates of pretreated wheat straw were further analyzed by liquid chromatography to quantify the amount of solubilised sugars. As shown in Table 3 both hexoses and pentoses as well as disaccharides were detected in hydrolysates of samples pretreated with selected white rot fungi. Data show that arabinose and xylose are the predominant monosaccharides in enzymatic hydrolisates of biologically pretreated samples. The significant amount of glucose was also detectable in samples but in the form of disaccharide cellobiose. The higher amount of glucose was released after chemical pretreatment of wheat straw with $\mathrm{NaOH}\left(18.4 \pm 0.2 \mathrm{~g} \mathrm{~L}^{-1}\right)$ while the minimum was noticed after pretreatment with $C$. cylindracea $\left(1.5 \pm 0.0 \mathrm{~g} \mathrm{~L}^{-1}\right)$. Maximum of cellobiose was measured in samples pretreated with $T$. versicolor $\left(19.2 \pm 0.5 \mathrm{~g} \mathrm{~L}^{-1}\right)$ and the minimum was detected after chemical pretreatment with $\mathrm{NaOH}\left(4.0 \pm 0.1 \mathrm{~g} \mathrm{~L}^{-1}\right)$. The maximal amount of arabinose was detected after pretreatment with $T$. versicolor $\left(18.0 \pm 0.3 \mathrm{~g} \mathrm{~L}^{-1}\right)$ while the highest amount of xylose was measured after enzymatic hydrolysis of untreated wheat straw $\left(42.7 \pm 1.2 \mathrm{~g} \mathrm{~L}^{-1}\right)$. The highest amounts of arabinose and xylose were measured after the pretreatmen with $C$. cylindracea $\left(1.2 \pm 0.0 \mathrm{~g} \mathrm{~L}^{-1}\right.$ and $3.7 \pm 0.0 \mathrm{~g} \mathrm{~L}^{-1}$, respectively).

Table 3

Hydrolysis efficiency of wheat straw (WS)

\begin{tabular}{|lll|}
\hline Sample & Hydrolysis yield $(\%)$ & Coefficient of conversion $\left(\boldsymbol{K}_{\mathrm{c}}\right)$ \\
\hline WS after Cyclocybe cylindracea cultivation & $9.4 \pm 0.5 \mathrm{E}^{\mathrm{a}}$ & $0.064 \mathrm{E}^{\mathrm{a}}$ \\
\hline WS after Ganoderma lucidum cultivation & $51.1 \pm 4.7 \mathrm{~B}$ & $0.335 \mathrm{~B}$ \\
\hline WS after Irpex lacteus cultivation & $21.8 \pm 2.9 \mathrm{D}$ & $0.084 \mathrm{~F}$ \\
\hline WS after Pleurotus ostreatus cultivation & $26.6 \pm 1.0 \mathrm{D}$ & $0.187 \mathrm{C}$ \\
\hline WS after Trametes versicolor cultivation & $25.3 \pm 2.0 \mathrm{D}$ & $0.132 \mathrm{D}$ \\
\hline Untreated WS & $34.2 \pm 0.3 \mathrm{C}$ & $0.342 \mathrm{~B}$ \\
\hline Chemically pretreated WS & $70.2 \pm 0.8 \mathrm{~A}$ & $0.660 \mathrm{~A}$ \\
\hline a Means with different letters within a column are significantly different $(\mathrm{P}<0.01)$ \\
\hline
\end{tabular}

Detection of pentoses in hydrolysates of samples indicating that significant residual amount of degraded hemicellulose is still present in samples after biological pretreatment. In addition, those sugars became available even after enzymatic hydrolysis conducted by cellulases. Finally, after simultaneous degradation of both cellulose and hemicellulose during biological pretreatment of wheat straw significant differences 
in amounts of released sugars can be observed. Thus, according to the sugar analysis pretreatment of wheat straw with $T$. versicolor caused the release of the highest amount of sugars (including hexoses and pentoses) during enzymatic hydrolysis.

As can be seen from Table 3 pretreatment with $\mathrm{NaOH}$ was strictly selective to cellulose degradation remaining hemicellulose none degraded. On the other hand, enzymatic hydrolysis of untreated wheat straw resulted in the highest amount of xylose.

\section{Discussion}

The substrate used for conversion to carbohydrates in this study was wheat straw pretreated with white-rot fungi applying fungal culturing as the method of pretreatment. Wheat straw is the material with the great potential as sustainable, abundant and the low cost biomass source in European countries ${ }^{16}$. Fungal culturing can be considered as environmental friendly and cost-effective method for pretreatment of lignocellulosic materials ${ }^{17,18}$

So far, considerable efforts were done in applying white-rot fungal species to pretreat lignocellulosic feedstock even during submerged or solidstate cultivation. The most frequently used species were from genera Bjerkandera, Ceriporiopsis, Ganoderma, Irpex, Phanerochaete, Pleurotus and Trametes ${ }^{17,18,19,20,21,22}$. Even though all these species are recognized as potent producers of ligninolytic enzymes during the cultivation on various substrates, significant variations in enzyme activities may occur depending on substrate. That is why is important to elaborate a physiological response on different types of carbon source for every single species or even strain used for pretreatment ${ }^{23}$. Previous studies showed that wheat straw is a suitable substrate for production of ligninolytic enzymes, indicating that the rate of delignification depends on specific enzymes production and the activity level ${ }^{12,14,15}$. Generally, peroxidises are predominantly responsible for lignin degradation and the level of their activity has to be significantly related to the rate of lignin degradation ${ }^{24}$. This is specifically attributed to initial phase of wood degradation when laccase has limited diffusion into non-degraded plant cell wall primarily due to molecule size. Species used for pretreatment of wheat straw in this study exhibited various capacities to produce ligninolytic enzymes and contribution of individual enzymes in the enzymatic pool was evident. High peroxidase activity in G. resinaceum, P. ostreatus and T. versicolor was expected and is in line with results reported by other authors $^{12,18,25}$. If not absent, laccase activity in all cases was higher at the beginning of cultivation expressing the trend of decrease in activity level after day 10 or day 15 , which was also observed in other researches ${ }^{26}$. This can be highly related to intensive degradation of small molecular weight compounds by laccase in the initial phase of fungal growth ${ }^{27}$. Comparing all studied species it can be observed that $I$. lacteus was the only species without laccase activity. MnP has been considered the main ligninolytic enzyme in I. lacteus which is in agreement with previous studies ${ }^{18}$.

Degradation of lignin during fungal growth on lignocellulosic substrate is inevitable process that enables access to both cellulosic and hemicellulosic oligomers. This is a key assumption that candidates this mechanism as a promising tool to be used in lignocelluloses pretreatment for bioethanol production ${ }^{28}$. Contrary to biodegradation processes which apply extracted ligninolytic enzymes targeting the lignin and its derivates only, during white-rot fungal culturing on solid lignocellulosic substrate, delignification is followed by the loss of carbohydrates to some extent ${ }^{18,29}$. However, fungal species which selectively degrade lignocellulose have higher affinity for lignin and degrade it faster than carbohydrate components ${ }^{30}$. Previous studies showed that approach of using selective lignin degraders could be of a great importance in biotechnology since the most of holocellulose after pretreatment remains in substrate, and are available for saccharification ${ }^{21}$.

Besides lignocelluloses feedstock preparation methods and physical parameters the factor that strongly affects enzymatic hydrolysis of cellulose is the proper amount of applied cellulolytic enzymes ${ }^{31}$. Obtained results clearly showed that increase of cellulase concentration over an optimal level of loading cannot cause higher rate of reducing sugars release. The main reason for this is that cellulose accessibility limits the effectiveness of minimum cellulase loading on the hydrolysis efficiency leaving the part of enzyme molecules unassociated to the substrate and with no effect on hydrolysis yield ${ }^{32}$.

Apart from enzyme concentration, particle size of lignocellulosic feedstock is also a factor that influences rate and efficiency of enzymatic hydrolysis ${ }^{33}$. This is mainly related to porosity and also substrate accessibility that has been discussed in literature for increased cellulosic conversions. Previous studies showed that particle size is correlated to hydrolysis efficiency indicating that smaller particles of lignocelluloses feedstock are more accessible to enzyme molecules due to lower degree of crystallinity and increased surface area ${ }^{34}$. Additionally, higher conversion can be attributed to improved mass and heat transfer in samples containing smaller particles ${ }^{33}$.

With previously defined optimal conditions referring to enzyme concentration and particle size, partial lignin degradation with white-rot fungi was investigated from the aspect of hydrolysis efficiency and overall convertibility. The effect of fungal pretreatment on enzymatic saccharification was evident according to obtained results. Studied fungal species exhibited various effectiveness in increasing saccharification which was mostly expected due to different physiological response of each fungus, influenced by different physical and chemical factors during the cultivation period $^{35}$. Thus, fungal culturing cannot always increase hydrolysis yield, and the positive effect depends on fungal species, the range of cultivation conditions and the substrate properties ${ }^{36}$. Besides our study, the positive effect of pretreatment with white-rot fungi has also been

Page $7 / 18$ 
observed by other authors ${ }^{17,18,36}$. The increase of hydrolysis yields is directly correlated to a better accessibility to polysaccharides after fungal delignification. Pinto et al. ${ }^{18}$ also reported that their strains of $G$. resinaceum and $T$. versicolor were the most effective among all tested species increasing saccharification about 2-fold. Results of biologically pretreated wheat straw clearly indicate that the higher rate of lignin in lignocellulosic feedstock decrees the efficiency of enzymatic hydrolysis which is in accordance with previous findings ${ }^{37}$. However, results of sugar analysis lead us to assume that this can be compensated with higher cellulose amount in feedstock after biological pretreatment where hemicelluloses was predominantly degraded which was observed in the case of P. ostreatus HAI592.

Nowadays, various chemical and physical methods are available to fractionate, solubilise, hydrolyze and separate fibre components of lignocelluloses. Those procedures are widely used in many refinery concepts for cellulosic ethanol production ${ }^{28}$. It is well known that different chemical methods used to process lignocelluloses promote the formation of various inhibitory compounds which are the main obstacle in subsequent fermentation with yeasts ${ }^{38}$. Thus, it is crucial to find the optimal pretreatment process not only to obtain the highest possible amount of fermentable sugars but to avoid formation of inhibitors as much as possible. Therefore, the examination of effectiveness of biological pretreatment was conducted by comparison with chemical pretreatment as predominantly used for lignocelluloses feedstock processing. Earlier researches pointed out that chemical pretreatments of lignocelluloses are more effective comparing with biological pretreatment. This is mainly based on the partial loss of holocellulose which is consumed by fungi during their growth and is used as carbon source ${ }^{39,40}$. A selection of fungal species with lower cellulase activity and selective degradation of lignin can be approach to improve biological pretreatment with white-rot fungi ${ }^{17}$. As the potential way to increase the efficiency of biological pretreatment some authors suggest the use of genetically modified organisms or a combination of biological with chemical pretreatment ${ }^{40}$.

Even though carbohydrates loss is expected during pretreatment with white rot fungi the relative carbohydrate enrichment of the biomass, i.e. by comparing the ratio carbohydrates:lignin in pretreated wheat straw samples was relatively lower. Previous research also showed that the decrease in wheat straw lignin as the result of fungal culturing produced a low enhancement of carbohydrate component by increasing glucan ratio in the biomass ${ }^{28}$. Pretreatment of lignocellulosic biomass with white rot fungi such as I. lacteus and Ceriporiopsis subvermispora have been previously studied ${ }^{41,42,43}$. As in the occasion of G. resinaceum of our study, an efficient enzymatic conversion of pretreated lignocellulosic material was achieved, but the increased conversion came at the expense of considerable loss of holocellulose during pretreatment. Furthermore, a positive effect of delignification has not been seen always. These inequalities occurred either due to weak delignification rate or as a result of substantial total solids loss ${ }^{43}$. Although higher coefficient of conversion was not achieved in biologically pretreated samples the approach still remains justified, as results of this study indicate that the crucial moment can be the period of fungal culturing in which the effect of an upconcentration of carbohydrates should be stopped after partial delignification, to avoid substantial sugar consumption by fungi.

Comparing with biologically pretreated wheat straw after chemical pretreatment with $\mathrm{NaOH}$ the higher amount of fermentable sugars was released. Considerably higher amounts of glucose and cellobiose and negligible presence of pentoses in hydrolysate of alkali pretreated wheat straw was the result of selective removal of lignin from biomass ${ }^{44}$. Process was followed by removal of acetyl and uronic acid groups on hemicelluloses and hydrolysis of ester linkages between xylan and hemicelluloses residues. All together this largely improved cellulose digestibility exhibiting minor cellulose loss comparing with fungal pretreated samples ${ }^{44}$. Previous studies also showed that chemical pretreatment is more efficient than biological pretreatment due to the partial loss of carbohydrates which are the carbon source for fungal growth ${ }^{40}$. Another impact of enzymatic hydrolysis of pretreated wheat straw was the accumulation of cellobiose. This was due to limitation in beta-glucosidase activity in enzymatic solution applied for saccharification. However, the presence of cellobiose in hydrolysate cannot be considered disadvantageous because this disaccharide can easily be converted to glucose either enzymatic or by using engineered yeast strains $^{37}$

\section{Conclusions}

Results of this study show the considerable potential of white-rot fungi in preparing lignocellulosic biomass for efficient production of fermentable sugars and further industrial scale processing to ethanol. Different fungal species have a various ability to degrade lignin in wheat straw and the rate of sugar consumption should be considered. A key mechanism of carbohydrate component convertibility enhancement is selective lignin removal in the biomass. Among tested species only Ganoderma resinaceum deserves to be considered as a promising lignin degrader after additional optimization of process parameters. Long time consumption, the low sugar yields and unpredictable fungal response to culturing conditions are the main challenge of the fungal pretreatment process in the conversion of lignocellulosic biomass.

\section{Methods}

Chemicals

All reagents and chemicals were of analytical grade and were purchased either from Sigma-Aldrich (St. Louis, MO, USA) or from Merck Millipore (Darmstadt, Germany), unless otherwise stated. 
Organisms

Fungal isolates used in the study were obtained from the culture collection of the Institute of Botany, Faculty of Biology, University of Belgrade (BEOFB) or from the culture collection of the Institute of Evolution, University of Haifa, Israel (HAI): Cyclocybe cylindracea BEOFB1210 (MW176087, 100\%), Ganoderma resinaceum BEOFB440 (MW176072, 100\%), Irpex lacteus BEOFB1910 (MH671316, 99.83\%), Pleurotus ostreatus HAI592 (MW176092, 91.99\%), Trametes versicolor BEOFB321 (MW176038, 99.64\%). Identification of fungal species was confirmed by ITS gene sequencing and the PCR amplification of this region was conducted as described by Savković et al. ${ }^{45}$. Gene bank accession numbers and homology percentages are given in brackets for each fungal isolate.

Preparation of lignocellulosic material

Wheat straw (Triticum aestivum L.) was washed with warm distilled water $\left(\mathrm{T}=50^{\circ} \mathrm{C}\right)$, dried in a heating oven (BINDER ED53) at $65^{\circ} \mathrm{C}$, to constant weight, grounded in the laboratory mixer (Waring $8010 \mathrm{~S}$ ), and sieved to obtain pieces of $0.5-2.0 \mathrm{~cm}$. So prepared wheat straw was subject to biological and chemical pretreatment.

Biological pretreatment

\section{Inoculum preparation}

Inoculum was prepared for each tested species by inoculating $100 \mathrm{~mL}$ of synthetic medium (glucose, $10.0 \mathrm{~g} \mathrm{~L}^{-1} ; \mathrm{NH}_{4} \mathrm{NO}_{3}, 2.0 \mathrm{~g} \mathrm{~L}^{-1} ; \mathrm{K}_{2} \mathrm{HPO}_{4}, 1.0$ $\mathrm{g} \mathrm{L}^{-1} ; \mathrm{NaH}_{2} \mathrm{PO}_{4} \times \mathrm{H}_{2} \mathrm{O}, 0.4 \mathrm{~g} \mathrm{~L}^{-1} ; \mathrm{MgSO}_{4} \times 7 \mathrm{H}_{2} \mathrm{O}, 0.5 \mathrm{~g} \mathrm{~L}^{-1}$; yeast extract, $2.0 \mathrm{~g} \mathrm{~L}^{-1} ; \mathrm{pH}$ 6.5) and incubation as previously described ${ }^{46}$.

\section{Cultivation conditions and extraction of ligninolytic enzymes}

Solid-state culturing was carried out at $25^{\circ} \mathrm{C}$ in $250 \mathrm{~mL}$ flasks containing $6.0 \mathrm{~g}$ of wheat straw and $30.0 \mathrm{~mL}$ of the modified synthetic medium (without glucose). Inoculation was done with $9.0 \mathrm{~mL}$ of inoculum per flask). Samples were harvested after 5, 10, 15 and 19 days of culturing and further used for ligninolytic enzyme extraction, according to previously established conditions ${ }^{46}$. The residues were used for determination of hemicelluloses, cellulose and lignin contents and for enzymatic saccharification.

Ligninolytic enzymes were extracted by stirring samples with $150.0 \mathrm{~mL}$ of cold $\mathrm{dH}_{2} \mathrm{O}$ on a magnetic stirrer at $4^{\circ} \mathrm{C}$ for 10 min. The extracts were filtrated using a laboratory sieve, the liquid fractions were centrifuged $\left(4^{\circ} \mathrm{C}, 3000 \mathrm{rpm}, 10 \mathrm{~min}\right)$ and the supernatants obtained were used for determining laccase and Mn-oxidizing peroxidases activities spectrophotometrically (CECIL CE2501 (BioQuest)). Solid phase remained after the extraction was dried in a drying oven at $65^{\circ} \mathrm{C}$ to constant weight.

\section{Enzyme activity assay and determination of total protein content}

Laccase (EC 1.10.3.2) activity was determined by monitoring the $A_{436}$ change related to the rate of oxidation of $50.0 \mathrm{mM} 2,2 \rrbracket$-azino-bis-[3ethylthiazoline-6-sulfonate] (ABTS) $\left(\varepsilon_{436}=29300 \mathrm{M}^{-1} \mathrm{~cm}^{-1}\right)$ in $0.1 \mathrm{M}$ phosphate buffer $(\mathrm{pH} 3.5)$ at $35^{\circ} \mathrm{C}$. The reaction mixture $\left(\mathrm{V}_{\text {tot }}=1.0 \mathrm{~mL}\right)$ contained buffer, ABTS and sample 25 .

Mn-oxidizing peroxidases (Mn-dependent peroxidase [EC 1.11.1.13; MnP] and Mn-independent peroxidase [EC 1.11.1.6; MnIP]) activities were determined with $3.0 \mathrm{mM}$ phenol red $\left(\varepsilon_{610}=22000 \mathrm{M}^{-1} \mathrm{~cm}^{-1}\right)$ as a substrate, in a succinate buffer $\mathrm{pH} 4.5$. The reaction mixture $\left(\mathrm{V}_{\text {tot }}=1.0 \mathrm{~mL}\right)$ contained buffer, sample, $2.0 \mathrm{mM} \mathrm{H}_{2} \mathrm{O}_{2}$ and phenol red, with or without $2.0 \mathrm{mM} \mathrm{MnSO}_{4}$ (for MnP and MnIP, respectively). The reaction was stopped by adding $2.0 \mathrm{M} \mathrm{NaOH}^{25}$.

Enzymatic activity of $1 \mathrm{U}$ is defined as the amount of enzyme that transforms $1.0 \mu \mathrm{mol}$ of substrate per min.

Determination of polymer content in a straw

\section{Hemicellulose content determination}

Content of hemicellulose was determined by Van Soest fibre analysis method by removing soluble sugars, proteins, pectin, lipids, and vitamins from the sample using neutral detergent and $\mathrm{Na}_{2} \mathrm{SO}_{3}{ }^{47,48}$. Thus neutral detergent fibres (NDF) were treated acid detergent solution to obtain acid detergent fibres (ADF). Hemicellulose content is than expressed as NDF-ADF.

\section{Cellulose and lignin content determination}

ADF were used for determining cellulose and lignin content using the $\mathrm{Klason}$ or $72 \% \mathrm{H}_{2} \mathrm{SO}_{4}$ method ${ }^{49}$. ADF were treated with $72 \% \mathrm{H}_{2} \mathrm{SO}_{4}$ and the Klason lignin residues were collected. Lignin content (LC) is expressed as a percentage of the original sample. Cellulose content is presented as the difference in weights of the samples treated with ADF and LC. 
Pretreated wheat straw was ground in the laboratory mixer and sieved to separate large fraction ( $\mathrm{L}, 5-8 \mathrm{~mm})$, medium fraction ( $\mathrm{M}, 2-5 \mathrm{~mm})$ and small fraction (S, $0.2-0.5 \mathrm{~mm}$ ). Enzymatic saccharifications were carried out in 250-mL flasks containing $2 \mathrm{~g}$ of pretreated straw in $60 \mathrm{~mL}$ of acetate buffer ( $\mathrm{pH} 4.8)$ with addition of streptomycin sulphate $\left(500 \mathrm{mg} \mathrm{L}^{-1}\right)$ to prevent bacterial growth, and commercial cellulase (Cellulase from Trichoderma reesei, C2730-50ML, $700 \mathrm{U} \mathrm{g}^{-1}$; Sigma-Aldrich) in loading of $0.5,1.0$ or $2.0 \mu \mathrm{L}$ per $\mathrm{mL}$ of mixture prepared for hydrolysis. Incubation was carried out in a shaking incubator with horizontal rotary plate (Stuart SI500) (180 rpm, $50^{\circ} \mathrm{C} \mathrm{for} 72 \mathrm{~h}$ ). Immediately after hydrolysis samples were immersed in boiling water for 5 min to inactivate the enzymes and further used for determination of reducing sugar content ${ }^{50}$.

Autoclaved untreated wheat straw was used as a negative control while chemically pretreated wheat straw was used as a positive control. Chemical pretreatment of wheat straw was performed with $1 \%(\mathrm{w} / \mathrm{v}) \mathrm{NaOH}$ at $121^{\circ} \mathrm{C}$ for 90 min. The samples were than washed with $\mathrm{dH} \mathrm{H}_{2} \mathrm{O}$ till $\mathrm{pH}$ 6.8-7.5 was achieved and the solid phase was further dried to constant weight and used for enzymatic hydrolysis ${ }^{51}$.

Reducing sugars content determination

The content of reducing sugars was measured colorimatrically using 1,4-dinitrosalycilic acid, according to the method of Miller ${ }^{52}$. Sampling of the liquid fraction of hydrolysate was performed periodically (after $6,12,24,36,48$ and $72 \mathrm{~h}$ ). Samples were centrifuged ( $15000 \mathrm{rpm}, 30^{\circ} \mathrm{C}, 10$ $\mathrm{min}$ ) and the supernatant was further used for quantitative determination of reducing sugars. The reaction mixture containing $1 \mathrm{~mL}$ of $\mathrm{DNSA}$ solution (aqueous solution of 1,4-dinitrosalic acid, $10.0 \mathrm{~g} \mathrm{~L}^{-1}$; potassium sodium tartarate tetrahydrate, $30.0 \mathrm{~g} \mathrm{~L}-1 ; 2 \mathrm{M} \mathrm{NaOH}, 200 \mathrm{~mL} / \mathrm{L}$ ) and 1 $\mathrm{mL}$ of sample was incubated at $90 \pm 0.5^{\circ} \mathrm{C}$ in a water bath for 5 min and cooled till room temperature $\left(22 \pm 2^{\circ} \mathrm{C}\right)$. After that, the mixture was diluted with $5 \mathrm{~mL}$ of $\mathrm{dH}_{2} \mathrm{O}$ and the amount of reducing sugars was determined spectrophotometrically by monitoring the absorbance at $540 \mathrm{~nm}$ against blank (containing $1 \mathrm{~mL}$ of acetate buffer ( $\mathrm{pH} 4.8$ ) instead of sample). Reducing sugars were expressed as $\mathrm{g}$ of glucose equivalent (gGE) per $L$ of hydrolysate using equation of calibration curve for glucose.

The yield of enzymatic hydrolysis was calculated as follows:

Hydrolysis yield $(\%)=$ Reducing sugars in hydrolysate $(\mathrm{g}) \times 0.9 \times 100 /$ Cellulose in sample $(\mathrm{g})$

The correlation factor of 0.9 corresponding to hexoses was used in the calculations to compensate for the addition of a water molecule during hydrolysis of each glycosidic bound ${ }^{53}$.

To determine the impact of fungal cultivation on an overall wheat straw conversion to glucose, the coefficient of conversion $\left(K_{\mathrm{c}}\right)$ from the maximal theoretical value (1) of an initial sample was calculated as follows:

$K_{\mathrm{c}}=\mathrm{m}_{\mathrm{f}} \times 0.9 /$ Cellulose in an initial sample $(\mathrm{g})$

Factor $m_{f}$ corresponds to the amount of reducing sugars $(\mathrm{g})$ obtained after saccharification of entire pretreated sample.

Analysis of sugars

Sugars (glucose, arabinose celibiose and xylose) were analyzed by high performance anion exchange chromatography. All aqueous solutions

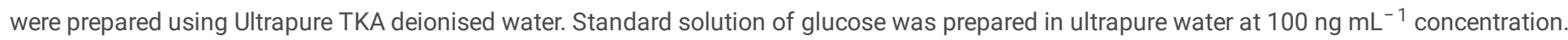
Calibration standards were prepared from these stock solutions by dilution with ultrapure water. The quality control mixture used for monitoring instrument performance was prepared by diluting standards to concentrations of $20 \mathrm{ng} \mathrm{mL}^{-1}$. Chromatographic separations were performed using DIONEX ICS 3000 DP liquid chromatography system (Dionex, Sunnyvale, CA, USA) equipped with a quaternary gradient pump (Dionex, Sunnyvale, CA, USA). Carbohydrates were separated on a Carbo Pac®PA100 pellicular anion-exchange column (4×250 mm) (Dionex, Sunnyvale, $\mathrm{CA}, \mathrm{USA}$ ) at $30^{\circ} \mathrm{C}$, whereas the mobile phase consisted of the following linear gradients (flow rate, $0.7 \mathrm{~mL} / \mathrm{min}$ ): $0-5 \mathrm{~min}, 15 \% \mathrm{~A}, 85 \% \mathrm{C} ; 5.0$ 5.1min, 15\% A, 2\% B, 83\% C; 5.1-12 min, 15\% A, 2\% B, 83\% C; $12-12.1 \mathrm{~min}, 15 \%$ A, 4\% B, 81\% C; $12.1-20 \mathrm{~min} 15 \%$ A, 4\% B, 81\% C; $20-20.1 \mathrm{~min} 20 \%$ A, 20\% B, 60\% C; 20.1-30 min 20\% A, 20\% B, 60\% C; where A is $600 \mathrm{mM}$ sodium hydroxide, $B$ is 600 mM sodium acetate and $C$ is ultrapure water. Before analysis system was preconditioned at $15 \%$ A, 85\% C; for 15 minutes. Each sample (25 $\mu \mathrm{L})$ was injected with an ICS AS-DV 50 auto sampler (Dionex, Sunnyvale, CA, USA). The pulsed amperometric detection was performed on gold as working and $\mathrm{Ag} / \mathrm{AgCl}$ as reference electrode.

Statistical analyses

The assays were carried out in three replicates and results are expressed as mean \pm standard error. Normal distribution (Shapiro-Wilks test) and homogeneity of variance (Levene's test) were evaluated prior to further analyses where certain groups based on different quantitative parameters were compared to see are there significant differences between them. If data followed normal distribution and homogeneity of variance was met,

Page 10/18 
one-way analysis of variance (ANOVA) was performed to test any significant differences among means, since the number of groups was always higher than two. If data followed a normal distribution, but the assumption of equal variances was violated, Welch Test or Welch ANOVA was considered for the analyses. Together with one-way ANOVA, the pairwise comparison option that runs Tukey's HSD (Honestly Significant Difference) post-hoc test was applied in some cases. Statistical significance was declared at $P<0.01$. All statistical analyses were performed using Microsoft Excel, the statistical package XLSTAT ${ }^{54}$ and software STATISTICA, version 6.0 (StatSoft, Inc., Tulsa, USA).

Principal component analysis (PCA) showing the relationship between the degradation of lignin and ligninolytic enzyme activities of all taxa was performed, for each enzyme separately. The values of lignin degradation by selected fungal species were used as response variables, while the enzyme activity of the taxa and time variable showing the number of days after which the measurements were performed were used as supplementary ones. Multivariate analyses were done using Canoco 5 software ${ }^{55}$.

\section{Declarations}

\section{Acknowledgments}

This research was financially supported by the Ministry of Education, Science, and Technological Development of the Republic of Serbia (Grant number: 451-03-68/2020-14/200178; Grant number: 173032; Grant number: 451-03-68/2020-14/200168).

\section{Authors' contributions}

AK and JV designed experiments. AK, IĐ and TT conceived experiments. AK, IĐ, TT and SP drafted the manuscript. AK, IĐ and JV interpreted data. SP performed statistical analysis and contributed to data interpretation. JV and DMO helped to revise the manuscript and supervised the project. All authors read and approved the final manuscript.

\section{Competing interests}

The authors declare that they have no competing interests.

\section{References}

1. Novy, V., Longus, K. \& Nidetzky, B. From wheat straw to bioethanol: Integrative analysis of a separate hydrolysis and co-fermentation process with implemented enzyme production. Biotechnol. Biofuels. https://doi.org/10.1186/s13068-015-0232-0 (2015).

2. Lee, H. R., Kazlauskas, R. J. \& Tai, H. P. One-step pretreatment of yellow poplar biomass using peracetic acid to enhance enzymatic digestibility. Sci. Rep. https://doi.org/10.1038/s41598-017-12542-w (2017).

3. Wettstein, S. G., Alonso, D. M., Gürbüz, E. I. \& Dumesic, J. A. A roadmap for conversion of lignocellulosic biomass to chemicals and fuels. Curr. Opin. Chem. Eng. 1, 218-224 (2012).

4. Parthasarathi, R. et al. Activation of lignocellulosic biomass for higher sugar yields using aqueous ionic liquid at low severity process conditions. Biotechnol. Biofuels. https://doi.org/10.1186/s13068-016-0561-7 (2016).

5. Su, Y. et al. Evaluation of screened lignin-degrading fungi for the biological pretreatment of corn stover. Sci. Rep. https://doi.org/10.1038/s41598-018-23626-6 (2018).

6. Hansen, M. A. T., Kristensen, J. B., Felby, C. \& Jorgensen, H. Pretreatment and enzymatic hydrolysis of wheat straw (Triticum aestivum L.) The impact of lignin relocation and plant tissues on enzymatic accessibility. Bioresour. Technol. 102, 2804-2811 (2011).

7. Talebnia, F., Karakashev, D. \& Angelidaki, I. Production of bioethanol from wheat straw: An overview of pretreatment, hydrolysis and fermentation. Bioresour. Technol. 101, 4744-4753 (2010).

8. Menon, V. \& Rao, M. Trends in bioconversion of lignocellulose: Biofuels, platform chemicals \& biorefinery concept. Prog. Energy Combust. Sci. 38, 522-550 (2012).

9. Janusz, G. et al. Lignin degradation: microorganisms, enzymes involved, genomes analysis and evolution. FEMS Microbiol. Rev. 41, 941-962 (2017).

10. Sánchez, C. Lignocellulosic residues: biodegradation and bioconversion by fungi. Biotechnol. Adv. 27, 185-194 (2009).

11. Wan, C. \& Li, Y. Fungal pretreatment of lignocellulosic biomass. Biotechnol. Adv. 30, 1447-1457 (2012).

12. Knežević, A. et al. Induction of wheat straw delignification by Trametes species. Sci. Rep. https://doi.org/10.1038/srep26529 (2016).

13. Arora, D. S., Chander, M. \& Gill, P. K. Involvement of lignin peroxidase, manganese peroxidase and laccase in degradation and selective ligninolysis of wheat straw. Int. Biodeterior. Biodegr. 50, 115-120 (2002).

14. Knežević, A. et al. Lignin degradation by selected fungal species. Bioresour. Technol. 138, 117-123 (2013a). 
15. Knežević, A., Milovanović, I., Stajić, M. \& Vukojević, J. Potential of Trametes species to degrade lignin. Int. Biodeterior. Biodegr. 85, 52-56 (2013b).

16. Kim, S. \& Dale, B. Global potential bioethanol production from wasted crops and crop residues. Biomass.Bioenergy. 4, 361-375 (2004).

17. Dias, A. A. et al. Enzymatic saccharification of biologically pre-treated wheat straw with white-rot fungi. Bioresour. Technol. 101, 6045-6050 (2010).

18. Pinto, P. A. et al. Influence of ligninolytic enzymes on straw saccharification during fungal pretreatment. Bioresour. Technol. 111, 261-267 (2012).

19. Isroi, I. et al. Biological pretreatment of lignocelluloses with white-rot fungi and its applications. Bioresources. 6, 5224-5259 (2011).

20. López-Abelairas, M. et al. Optimisation of the biological pretreatment of wheat straw with white-rot fungi for ethanol production. Bioprocess. Biosyst. Eng. 36, 1251-1260 (2013).

21. Nazarpour, F., Abdullah, D. K., Abdullah, N. \& Tamiri, Z. Evaluation of biological pretreatment of rubberwood with white rot fungi for enzymatic hydrolysis. Materials. https://doi.org/10.3390/ma6052059 (2013).

22. Vasco-Correa, J. \& Shah, A. Techno-economic bottlenecks of the fungal pretreatment of lignocellulosic biomass. Fermentation. https://doi.org/10.3390/fermentation5020030 (2019).

23. Gómez, S. Q., Arana-Quenca, A., Flores, Y. M., Rodríguez, J. N. G. \& Téllez-Jurado, A. Effect of particle size and aeration on the biological delignification of corn straw using Trametes sp. 44. Bioresources. 7, 327-344 (2012).

24. Schmidt, O. Wood and three fungi: Biology, damage, protection and use. Springer-Verlag, Berlin, Heidelberg, pp. 138-139 (2006).

25. Stajić, M. et al. Wheat straw conversion by enzymatic sistem of Ganoderma lucidum. Biol. Res. 5, 2362-2373 (2010).

26. Schlosser, D., Grey, R. \& Fritsche, W. Patterns of ligninolytic enzymes in Trametes versicolor. Distribution of extra- and intracellular enzyme activities during cultivation of glucose, wheat straw and beech wood. Appl. Microbiol. Biotechnol. 47, 415-418 (1997).

27. Piscitelli, A. et al. Induction and transcriptional regulation of laccases in fungi. Curr. Genomics. 12, 104-112 (2011).

28. Thomsen, S. T. et al. Combination of ensiling and fungal delignification as effective wheat straw pretreatment. Biotechnol. Biofuels. https://doi.org/10.1186/s13068-016-0437-x (2016).

29. Rodrígues, M. A. M. et al. Effect of enzyme extract isolated from white-rot fungi on chemical composition and in vitro digestibility of wheat straw. Anim. Feed. Sci. Technol. 141, 326-38 (2008).

30. Hatakka, A. I. Pretreatment of wheat straw by white-rot fungi for enzymatic saccharification of cellulose. Appl. Microbiol. Biotechnol. 18, 350357 (1983).

31. Tsegaye, B., Balomajunder, C. \& Roy, P. Microbial delignification and hydrolysis of lignocellulosic biomass to enhance biofuel production: an overview and future prospects. Bull. Natl. Res. Cent. https://doi.org/10.1186/s42269-019-0094-x (2019).

32. Arantes, V. \& Saddler, J. N. Cellulose accessibility limits the effectiveness of minimum cellulose loading on the efficient hydrolysis of pretreated lignocellulosic substrates. Biotechnol. Biofules.4, 3 (2011).

33. Khullar, E., Dien, B. S., Rausch, K. D., Tumbleson, M. E. \& Singh, V. Effect of particle size on enzymatic hydrolysis of pretreated Miscanthus. Ind. Crops. Prod. 44, 11-17 (2013).

34. Ghosh, P. \& Ghose, T. K. Bioethanol in India: Recent Past and Emerging Future. Adv. Biochem. Eng. Biotechnol. 85, 1-27 (2003).

35. Viniegra-González, G. et al. Advantages of fungal enzyme production in solid state over liquid fermentation systems. Biochem. Eng. J. 13, 157-167 (2003).

36. Fang, W. et al. Evaluation of white rot fungi pretreatment of mushroom residues for volatile fatty acid production by anaerobic fermentation: Feedstock applicability and fungal function. Bioresour. Thechnol. 297, 122447 (2020).

37. Buzala, K. P., Kalinowska, H., Przybysz, P. \& Malachowska, E. Conversion of various types of lignocellulosic biomass to fermentable sugars using kraft pulping and enzymatic hydrolysis. Wood Sci. Technol. 51, 873-885 (2017).

38. Avci, A., Saha, B. C., Kennedy, G. J. \& Cotta, M. A. Dilute sulfuric acid pretreatment of corn stover for enzymatic hydrolysis and efficient ethanol production by recombinant Escherichia coli FBR5 without detoxification. Bioresour. Technol. 142, 312-219 (2013).

39. Chen, Y., Sharma-Shivappa, R. R., Keshwani, D. \& Chen, C. Potential of agricultural residues and hay for bioethanol production. Appl. Biochem. Biotechnol. 142, 276-90 (2007).

40. Salvachúa, D. et al. Fungal pretreatment: An alternative in second-generation ethanol from wheat straw. Bioresour. Technol. 102, $7500-7506$ (2011).

41. Cui, Z., Wan, C., Shi, J., Sykes, R.W. \& Li, Y. Enzymatic digestibility of corn stover fractions in response to fungal pretreatment. Ind. Eng. Chem. Res. 51, 7153-7159 (2012).

42. Salvachúa, D. et al. Differential proteomic analysis of the secretome of Irpex lacteus and other white-rot fungi during wheat straw pretreatment. Biotechnol. Biofuels. https://doi.org/10.1186/1754-6834-6-115 (2013).

Page $12 / 18$ 
43. Cianchetta, S., Di Maggio, B., Burzi, P. L. \& Galletti, S. Evaluation of selected white-rot fungal isolates for improving the sugar yield from wheat straw. Appl. Biochem. Biotechnol. 173, 609-623 (2014).

44. Maurya, D. P., Singla, A. \& Negi, S. An overview of key pretreatment processes for biological conversion of lignocellulosic biomass to bioethanol. 3 Biotech. 5, 597-609 (2015).

45. Savković, Ž. et al. Diversity and seasonal dynamics of culturable airborne fungi in a cultural heritage conservation facility. Int. Biodeterior. Biodegr.157, 105163 (2021).

46. Knežević, A., Stajić, M., Milovanović, I. \& Vukojević, J. Degradation of beech wood and wheat straw by Trametes gibbosa. Wood Sci. Technol. 51, 1227-1247 (2017).

47. Goering, H. K. \& Van Soest, P. J. Forage Fiber Analysis (Apparatus Reagents, Procedures and Some Applications) in: Agriculture Handbook No. 379, United States Department of Agriculture, Washington DC 1-20 (1970).

48. Van Soest, P. J., Robertson, J. B. \& Lewis, B. A. Methods for dietary fiber, neutral detergent fiber and non-starch polysaccharides in relation to animal nutrition. J. Dairy. Sci. 74, 3583-3597 (1991).

49. Kirk, T. K. \& Obst, J. R. Lignin determination in: Methods in Enzymology161 (ed. Colowick, S. P. \& Kaplan, N.0.) $87-101$ (Academic Press Inc., 1988).

50. Lu, J., Li, X., Zhao, J. \& Qu, Y. Enzymatic saccharification and ethanol fermentation of reed pretreated with liquid hot water. J. Biomed. Biotechnol. https://doi.org/10.1155/2012/276278 (2012).

51. Han, L. et al. Alkali pretreated of wheat straw and its enzymatic hydrolysis. Braz. J. Microbiol. 53, 61 (2012).

52. Miller, G. L. Use of dinitrosalicylic acid reagent for determination of reducing sugar. Anal. Chem. 31, 426-428 (1959).

53. Van Dyk J. S. \& Pletschke B. I. A review of lignocellulose bioconversion using enzymatic hydrolysis and synergistic cooperation between enzymes - factors affecting enzymes, conversion and synergy. Biotechnol. Adv. 30, 1458-1480 (2012).

54. Addinsoft. XLSTAT statistical and data analysis solution. New York, USA. https://www.xlstat.com (2020).

55. Ter Braak, C. J. F \& Šmilauer, P. Canoco reference manual and user's guide: software for ordination, version 5.0. Microcomputer Power, Ithaca, USA (2012).

\section{Figures}


a

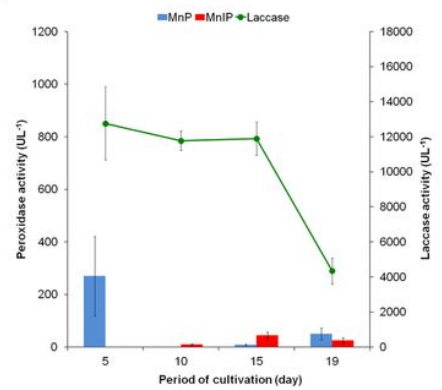

c

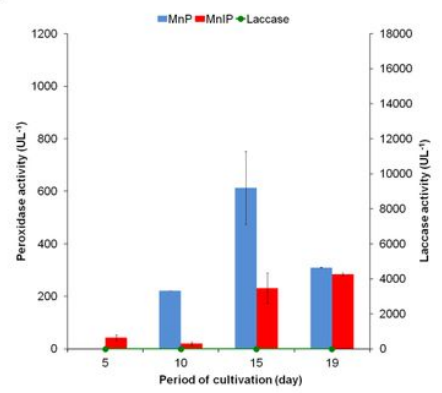

b

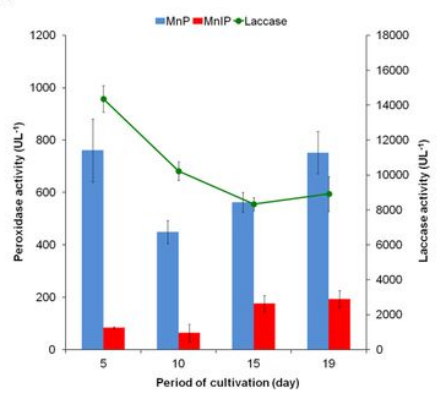

d



e

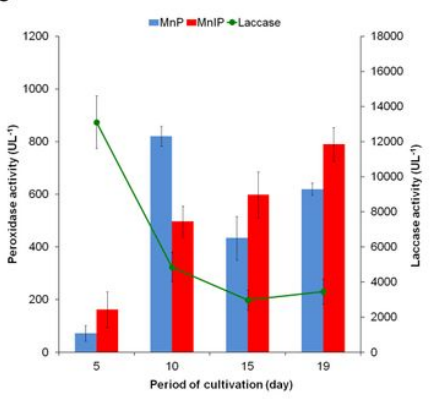

\section{Figure 1}

Dinamic of ligninolytic enzyme activity during solid-state culturing on wheat straw: a. Cyclocybe cylindracea; b. Ganoderma resinaceum; c. Irpex lacteus; d. Pleurotus ostreatus; e. Trametes versicolor. 
a

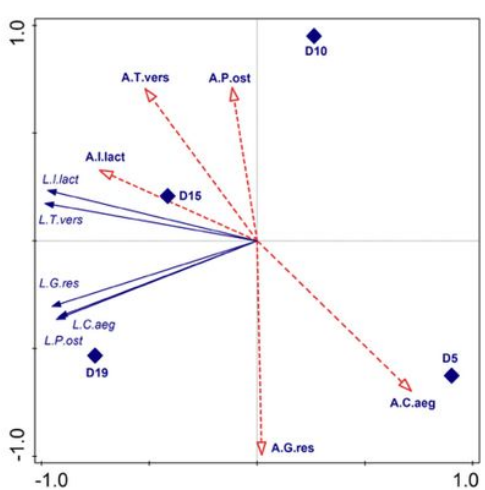

b


Figure 2

PCA representing the relationship between the degradation of lignin and enzyme activities of Cyclocybe cylindracea, Ganoderma resinaceum, Irpex lacteus, Pleurotus ostreatus and Trametes versicolor, for each enzyme separately: a. MnP; b. MnIP; c. laccase. Legend: C.aeg - Cyclocybe cylindracea; G.res - Ganoderma resinaceum; I.lact - Irpex lacteus; P.ost - Pleurotus ostreatus; T.vers - T. versicolor; prefix L - the degradation of lignin, prefix A - the activity of the enzyme; D5, D10, D15, D19 - variable referring to the number of days after which the degree of lignin degradation and enzyme activity were measured. 
a

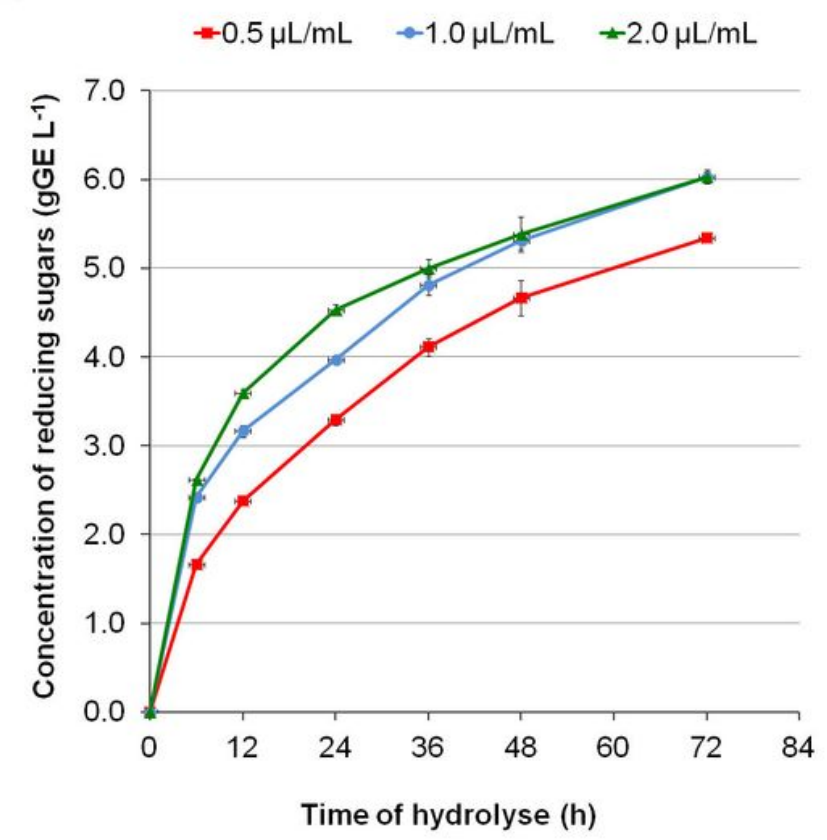

b

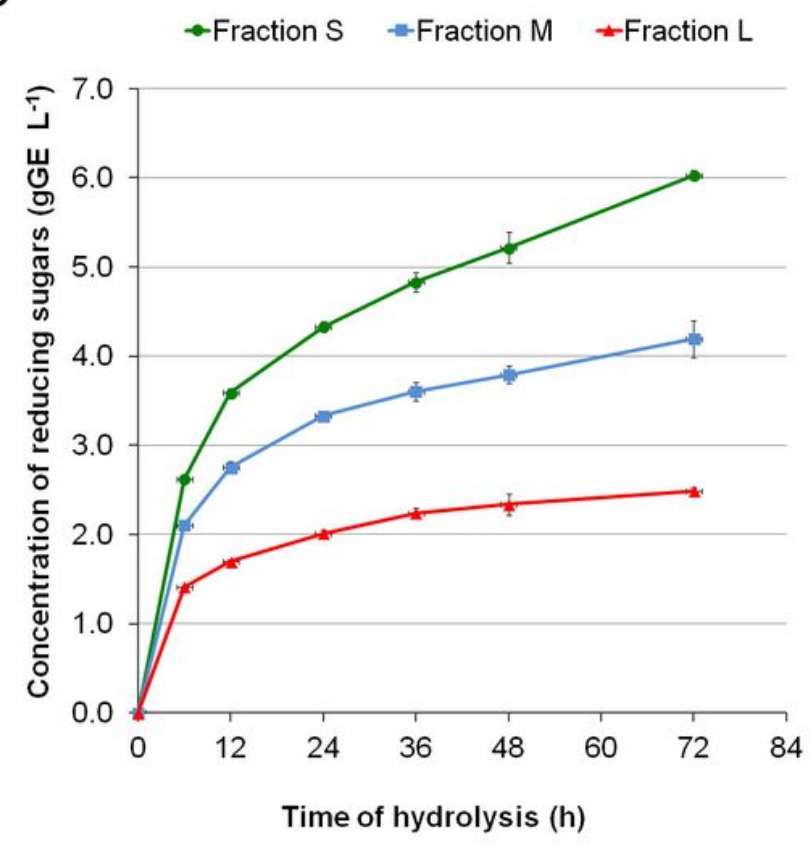

\section{Figure 3}

Time course of reducing sugars release from wheat straw during enzymatic saccharification: a. Effect of enzyme loading; b. Effect of particle size. 


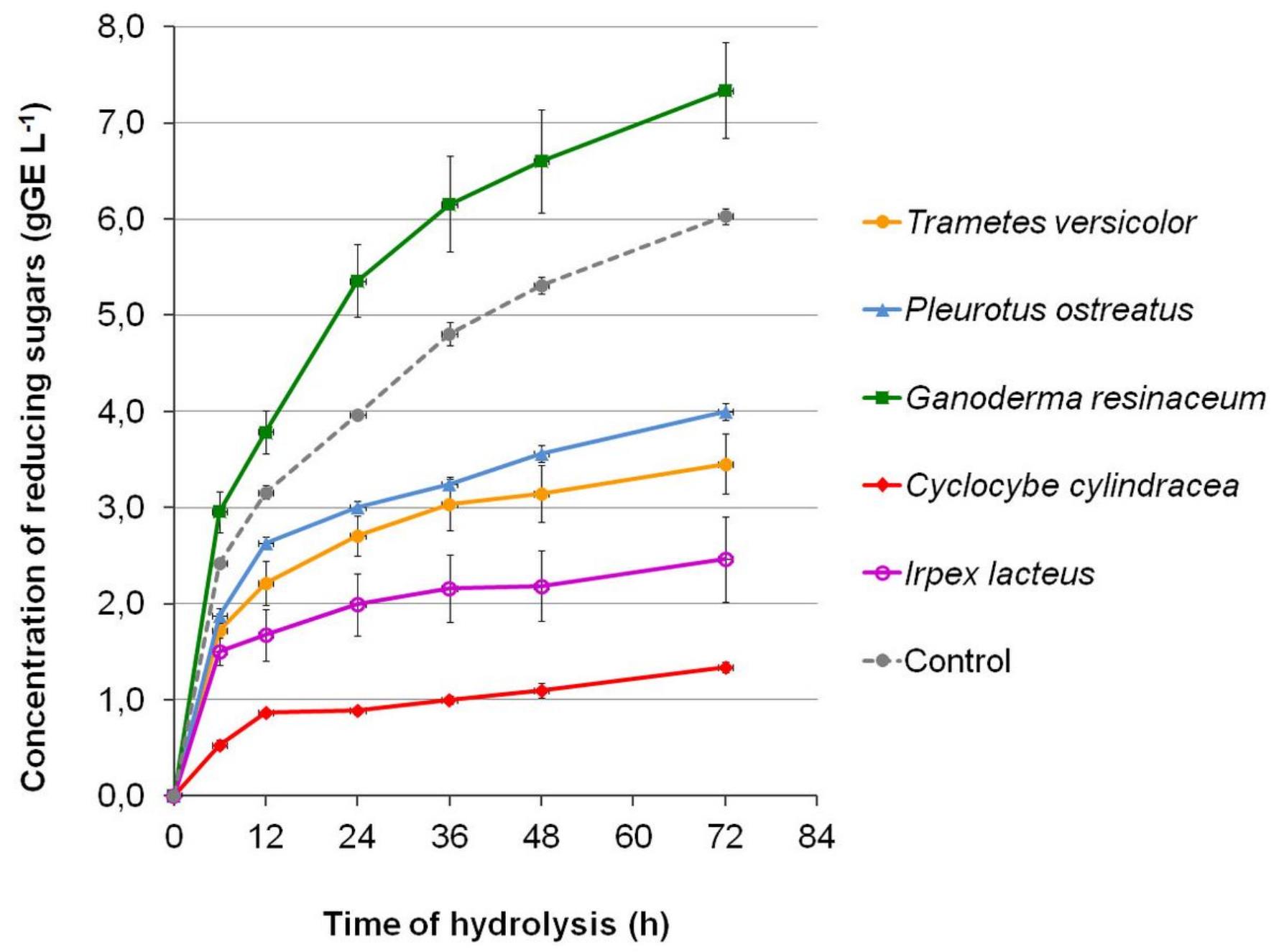

Figure 4

Time course of reducing sugars release from biologically pretreated wheat straw during enzymatic saccharification. 
$\rightarrow$ Untreated wheat straw $\rightarrow \mathrm{NaOH}$ pretreated wheat straw

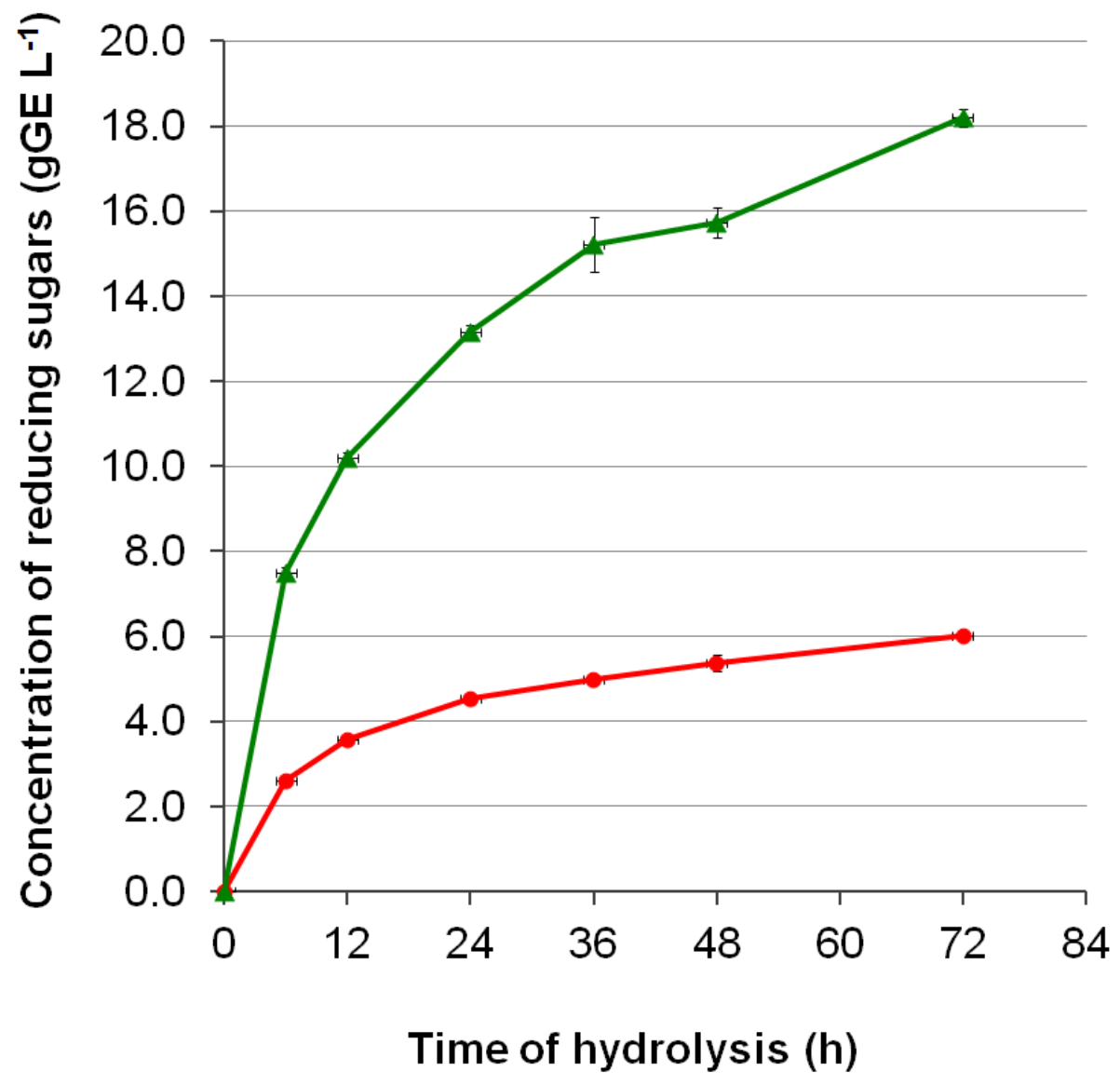

Figure 5

Time course of reducing sugars release from $\mathrm{NaOH}$-pretreated wheat straw during enzymatic saccharification. 